KERSTEN, Giselle Meira; FERREIRA, Marcelo Gitirana Gomes; ALVES, Paulo Roberto Ramos. Danos morais às mulheres nas relações de trabalho. Revista Eletrônica Direito e Política, Programa de PósGraduação Stricto Sensu em Ciência Jurídica da UNIVALI, Itajaí, v.14, n.1, 10 quadrimestre de 2019. Disponível em: www.univali.br/direitoepolitica - ISSN 1980-7791

\title{
DANOS MORAIS ÀS MULHERES NAS RELAÇÕES DE TRABALHO
}

\author{
MORAL DAMAGE TO WOMEN IN WORK RELATIONS
}

\author{
Giselle Meira Kersten ${ }^{1}$ \\ Marcelo Gitirana Gomes Ferreira ${ }^{2}$ \\ Paulo Roberto Ramos Alves ${ }^{3}$
}

\section{RESUMO}

O ambiente de trabalho é um meio social em que pessoas, cultural, intelectual e socialmente diferentes reúnem-se com objetivo que lhes é comum, o do exercício de atividade laboral. O empregador exerce poder de direção sobre o empregado, assim como fazem seus prepostos e por esta razão muitas vezes ultrapassam limites éticos e morais socialmente aceitos. São várias as formas de assédio moral cometidos no ambiente de trabalho além dos demais danos que podem ocorrer em virtude de acidentes de trabalho e outras práticas cometidas pelos empregadores contra seus empregados. Desde a Constituição Federal de 1988, os danos morais causados podem ser reparados através de indenizações que tem tanto o condão de punir e educar aquele que praticou o dano quanto compensar aquele que sofreu. O método utilizado para a pesquisa foi o indutivo, e como técnicas de pesquisa foi utilizada a revisão bibliográfica e jurisprudencial, através de análise de decisões proferidas pelo TRT da $12^{a}$ Região entre janeiro de 2017 e outubro de 2018 . As abordagens do estudo foram qualitativas. Verificou-se as razões do ingresso judicial requerendo a reparação dos danos morais sofridos e o entendimento dos tribunais, comparando-se as situações vividas entre homens e mulheres no meio ambiente de trabalho.

\footnotetext{
${ }^{1}$ Doutoranda em Administração pela ESAG/UDESC. Mestre em Ciência Jurídica pela Universidade do Vale do Itajaí (UNIVALI) em 2003. Graduada em Ciências Econômicas pela UFSC em 1998. Graduada em Direito pela UNIVALI em 1996. Professora do Curso de Graduação em Direito da UNIVALI e prof. assistente na ESAG/UDESC. Florianópolis, Santa Catarina, Brasil. Email: gisellekersten@hotmail.com.

2 Doutor e Mestre em Engenharia Mecânica pela Universidade Federal de Santa Catarina (UFSC), títulos obtidos respectivamente em 2006 e 1997. Realizou pós-doutorado em Design Cerâmico na A2D da UFSC em 2008. Graduação em Engenharia Mecânica pela Universidade Federal de Pernambuco em 1992. Professor associado do Departamento de Design/UDESC. Professor de graduação e pós-graduação, cursos de mestrado e doutorado. Florianópolis, Santa Catarina, Brasil. Email: marcelo.gitirana@gmail.com.

3 Doutor e Mestre em Direito pela Universidade do Vale dos Sinos (UNISINOS), títulos obtidos respectivamente em 2009 e 2015. Realizou pós-doutorado na Universidade de Passo Fundo (UPF) em 2016. Graduado em Direito pela Universidade de Passo Fundo em 2007. Professor permanente e Vice Coordenador do Programa de Pós-Graduação em Direito - Curso de Mestrado - da Universidade de Passo Fundo. Professor do Curso de Graduação em Direito da UPF. Passo Fundo, Rio Grande do Sul, Brasil. Email: pauloalves@yahoo.com.br
} 
KERSTEN, Giselle Meira; FERREIRA, Marcelo Gitirana Gomes; ALVES, Paulo Roberto Ramos. Danos morais às mulheres nas relações de trabalho. Revista Eletrônica Direito e Política, Programa de PósGraduação Stricto Sensu em Ciência Jurídica da UNIVALI, Itajaí, v.14, n.1, 10 quadrimestre de 2019. Disponível em: www.univali.br/direitoepolitica - ISSN 1980-7791

PALAVRAS-CHAVE: assédio; moral; mulher; trabalho.

\begin{abstract}
The work environment is a social environment in which people, culturally, intellectually and socially different meet with their common objective, the exercise of work activity. The employer exerts power of direction over the employee, just as his employees do, and for this reason often exceed socially accepted ethical and moral limits. There are various forms of harassment committed in the workplace in addition to other damages that may occur as a result of work-related accidents and other practices committed by employers against their employees. Since the Federal Constitution of 1988 , the moral damages caused can be repaired through indemnities that have as much to punish and educate the one who practiced the damage as to compensate the one who suffered. The method used for the research was the inductive one, and as research techniques the bibliographic review and analysis of decisions made by the TRT of the 12th Region between January 2017 and October 2018 were used. The approaches of the study were qualitative. It was verified the reasons for the judicial entry requesting the reparation of the moral damages suffered and the understanding of the courts, comparing the situations experienced between men and women in the working environment.
\end{abstract}

KEYWORDS: harassment, moral, woman, work.

\title{
INTRODUÇÃo
}

O estudo dos danos morais na esfera trabalhista tem gerado grandes discussões desde a prerrogativa constitucional de proteção à moral e reparação pelos danos causados. Os abalos morais aos empregados podem ser causados tanto pelos empregadores quanto por seus prepostos no exercício de suas funções. Admitese, ainda, que os empregados sofram danos morais causados por terceiros, alheios às relações diretas de trabalho, mas ainda ocorridos no meio ambiente de trabalho.

Os danos morais sofridos pelos empregados causam-lhe inúmeros males, físicos, psíquicos e sociais, retirando-lhe, muitas vezes, tanto a capacidade física laboral quanto o entusiasmo e segurança necessários para o desenvolvimento de qualquer atividade.

Estes danos são de naturezas diversas pois tanto podem ocorrer por atos (intencionais ou não) dentro do meio ambiente de trabalho por colegas de trabalho 
KERSTEN, Giselle Meira; FERREIRA, Marcelo Gitirana Gomes; ALVES, Paulo Roberto Ramos. Danos morais às mulheres nas relações de trabalho. Revista Eletrônica Direito e Política, Programa de PósGraduação Stricto Sensu em Ciência Jurídica da UNIVALI, Itajaí, v.14, n.1, 10 quadrimestre de 2019. Disponível em: www.univali.br/direitoepolitica - ISSN 1980-7791

ou seus superiores hierárquicos com objetivos específicos almejados de definhar e minguar a autoestima do empregado, como podem ser resultado de acidentes de trabalho ou descumprimento das obrigações contratuais que tenham gerado dano ao empregado.

Grande parte dos danos são sofridos por pessoas mais vulneráveis e que se diferem do que se concebe como comum, e o presente estudo refere-se às empregadas mulheres como as mais expostas à submissão a estes danos. Com base neste contexto, depara-se com a necessidade de se aclarar conceito de moral, elucidações acerca do dano moral e justificativas da fragilidade feminina nas relações de trabalho que geram danos morais.

Utilizando-se de abordagem qualitativa de pesquisa, primeiramente, com o uso da bibliometria, foi utilizada a base de dados da Capes para verificar artigos afins ao tema proposto. Posteriormente, para melhor elucidar, foram analisadas todas as decisões judiciais proferidas pelo Egrégio Tribunal Regional do Trabalho da $12^{a}$ Região referente ao período 01/01/2017 a 26/10/2018, que julgaram pedidos de indenização por danos morais sofridos pelos empregados.

\section{MORAL NAS RELAÇÕES DE TRABALHO}

A religião e a razão são duas fontes de orientação da ética e da moral. A base da ética é a emoção tendo em vista que os valores emanam dos sentimentos. A razão, por sua vez, ordena, disciplina e define a paixão, assim, direciona-se a uma ética utilitária, mais ponderada e denominada de ética promissora a paixão regrada pela justa razão. A ética coletiva, criada em uma "família humana", estrutura todos os valores ligados à vida, ao cuidado, ao trabalho, às relações cooperativas e à cultura da paz. ${ }^{4}$

Os termos gregos ethos e daimon, no séc. VI a.C., significam, respectivamente, "morada humana" e "anjo bom". Heráclito então definiu a base da ética na seguinte

\footnotetext{
${ }^{4}$ BOFF, Leonardo. Ética e moral: a busca dos fundamentos. 4 ed. Petrópolis: Vozes, 2009. p. 28-
} 29. 
KERSTEN, Giselle Meira; FERREIRA, Marcelo Gitirana Gomes; ALVES, Paulo Roberto Ramos. Danos morais às mulheres nas relações de trabalho. Revista Eletrônica Direito e Política, Programa de PósGraduação Stricto Sensu em Ciência Jurídica da UNIVALI, Itajaí, v.14, n.1, 10 quadrimestre de 2019. Disponível em: www.univali.br/direitoepolitica - ISSN 1980-7791

expressão: "a casa é o anjo bom do ser humano". A definição de casa é o conjunto das relações que o ser humano estabelece com o meio natural, local sagrado em que se espera mútua ajuda, gentileza, compreensão. Daimon é um bom sinal que exala do homem, proveniente de um ser superior. Parte-se do pressuposto que todo homem possui um Daimon que nos dá a libido, a inteligência, o amor e o poder. Ser bom é ser ético, ou seja, tudo o que fazemos para o bem. O contrário, o homem passa a ser mau quando possui vícios como a rigidez, a inflexibilidade e a a-historicidade. Define épsilon os costumes, usos, hábitos e tradições. Neste contexto, a expressão utilizada por Leonardo Boff, ethos, como sendo um local sagrado, estende-se também ao ambiente de trabalho. Um homem para ser bom precisa manter boas relações familiares e sociais e o local de trabalho passa a ser um ambiente em que as relações entre os indivíduos deve oportunizar um bom convívio capaz de o fazer feliz. ${ }^{5}$

No sistema capitalista, o lucro é necessário à perpetuação da empresa e para alcançar seu objetivo necessário o preenchimento de quatro condições essenciais: a existência da empresa, do capital que é a justa remuneração aos investidores como a retribuição societária, do trabalho é a parte para a remuneração do empregado através do recebimento de um salário justo e da comunidade cuja função social da empresa é atender as suas necessidades e com isto cumprir sua função de "solidariedade social". O objetivo da empresa é a prestação de serviços à sociedade, mas o lucro é o objetivo dos negócios. A felicidade na empresa busca de forma irrestrita as condições necessárias para a efetiva produtividade harmonizando-se afetivamente e proporcionando bem-estar psicológico-emocional para o exercício do amor entre as pessoas que trabalham. O gestor oferece segurança social e técnica ao compartilhar experiências e permitir que todos aprendam. Portanto, não restringe para si seus conhecimentos, mas ao compartilhar permite que seus empregados aprendam e sintam-se participantes

${ }^{5}$ BOFF, Leonardo. Ética e moral: a busca dos fundamentos. p. 32-36. 
KERSTEN, Giselle Meira; FERREIRA, Marcelo Gitirana Gomes; ALVES, Paulo Roberto Ramos. Danos morais às mulheres nas relações de trabalho. Revista Eletrônica Direito e Política, Programa de PósGraduação Stricto Sensu em Ciência Jurídica da UNIVALI, Itajaí, v.14, n.1, 10 quadrimestre de 2019. Disponível em: www.univali.br/direitoepolitica - ISSN 1980-7791

do processo de produção. Este ato consolida a solidariedade, identifica valores e as necessidades individuais e grupais. ${ }^{6}$

A prática da ética na organização promovida por verdadeiros líderes preserva e ressalta a dignidade humana, a liberdade e a igualdade e respeito aos direitos humanos. Portanto, com relação aos empregados, a gestão participativa deve permear estilos democráticos no trabalho, favorecer diálogos permanentes, incluir feedback e planejar ações em conjunto.

Muito se discute acerca da responsabilidade social das empresas em contraponto à noção de que o único objetivo do empresário era maximizar lucro. Os objetivos do empresário além deste é cuidar dos aspectos decorrentes do meio ambiente e das comunidades. Milton Friedman atribui às corporações o adjetivo de serem boas para a sociedade e o governo é ruim. As corporações buscam meios de maximizar lucros, e este é o seu imperativo moral. Seria considerado imoral às corporações a busca de objetivos sociais e ambientais em detrimento do lucro. Não é errado utilizar de meios sociais e ambientais em busca de lucro. ${ }^{7}$

Atualmente, quando se fala em meio ambiente, importante que se inclua a condição de trabalho, as relações entre os trabalhadores e o próprio local de trabalho. Se se alude que as relações de trabalho se incluem no ethos grego, um trabalhador feliz é aquele que é tratado dignamente como um ser humano, em respeito ao princípio constitucional da "dignidade da pessoa humana", sendo uma das garantias fundamentais. Para que as condições de trabalho garantam o respeito a este direito, as relações entre os trabalhadores e seus superiores hierárquicos deve ser saudável, excluindo-se a possibilidade de qualquer pressão psicológica ou agressão física. O local de trabalho deve ser preservado pela salubridade.

\footnotetext{
${ }^{6}$ MATOS, Francisco Gomes de. Ética na gestão empresarial, na conscientização à ação. São Paulo: Saraiva, 2008. p. 13-15.

7 BAKAN, Joel. A corporação. A busca patológica por lucro e poder. Tradução de Camila Werner. São Paulo: Novo Conceito Editora, 2008. p. 72.
} 
KERSTEN, Giselle Meira; FERREIRA, Marcelo Gitirana Gomes; ALVES, Paulo Roberto Ramos. Danos morais às mulheres nas relações de trabalho. Revista Eletrônica Direito e Política, Programa de PósGraduação Stricto Sensu em Ciência Jurídica da UNIVALI, Itajaí, v.14, n.1, 10 quadrimestre de 2019. Disponível em: www.univali.br/direitoepolitica - ISSN 1980-7791

\section{ASSÉDIO MORAL E DANO MORAL}

A ausência destes pressupostos citados pode gerar assédio moral muito recorrente nas relações de trabalho é reconhecido como um processo perverso no qual há manipulação e agressão de um, denominado assediado, e, em contrapartida, confirmação de poder e vantagens de outro, o assediador. ${ }^{8}$

O assédio moral no trabalho começou a ser estudado a partir da década de 80 . É assim denominado pelo desequilíbrio na relação entre empregado e empregador proveniente de atos praticados repetidamente. $O$ ato de assédio ou violência tanto pode ser praticado pelos próprios membros da empresa quanto por terceiros, externos a esta, mas o que configura o ato é a frequência com que é praticado e a duração. ${ }^{9}$

Ainda sobre o conceito de assédio moral, verifica-se que é a situação em que o empregado por incidência repetitiva é vítima de tratamento desrespeitoso, insultos, mentiras, exposição a situações vexatórias, chantagem e outros atos. ${ }^{10}$

Assédio Moral no Trabalho, designado como (AMT), é o comportamento hostil e antiético praticado por um indivíduo contra outro, repetidamente, considerado como ato de violência. É um dos fatores de risco à saúde dos trabalhadores também entendido como riscos psicossociais. A humanização nas relações de trabalho garante bem-estar aos trabalhadores e, segundo Walton, são decorrentes de oito aspectos: compensação ou remuneração justa e adequada; condições dignas de trabalho; uso e desenvolvimento das capacidades dos trabalhadores, concedendo-Ihes oportunidades de aperfeiçoamento e crescimento; segurança no

8 PINTO, Renata de Almeida Bicalho. PAULA, Ana Paula Paes de. Do assédio moral à violência interpessoal: Relatos sobre uma empresa júnior. Cad. EBAPE.BR, Rio de Janeiro, v. 11, n. 3, artigo 1. 2013.2 Det./nov. 2 Disponível http://bibliotecadigital.fgv.br/ojs/index.php/cadernosebape/article/view/7491. Acesso em: 05/05/2018. p. 342.

9 VALADÃO JÚNIOR, Valdir Machado. MENDONÇA, Juliana Moro Bueno. Assédio moral no trabalho: dilacerando oportunidades. Cad. EBAPE.BR, Rio de Janeiro: v. 13, no 1, artigo 2, jan./mar. 2015. Disponível em: http://www.scielo.br/pdf/cebape/v13n1/1679-3951-cebape-13-01-00019.pdf. Acesso em: 15/07/2018. p. 22.

10 FAIMAN, Carla Júlia Segre. A queixa de assédio moral no trabalho e na psicoterapia. Psicologia em Estudo, Maringá, v. 21, n. 1, p. 127-135. jan./mar. 2016. Disponível em: http://periodicos.uem.br/ojs/index.php/PsicolEstud/article/view/28311. Acesso em: 10/01/2018. p. 128. 
KERSTEN, Giselle Meira; FERREIRA, Marcelo Gitirana Gomes; ALVES, Paulo Roberto Ramos. Danos morais às mulheres nas relações de trabalho. Revista Eletrônica Direito e Política, Programa de PósGraduação Stricto Sensu em Ciência Jurídica da UNIVALI, Itajaí, v.14, n.1, 10 quadrimestre de 2019. Disponível em: www.univali.br/direitoepolitica - ISSN 1980-7791

ambiente de trabalho e na perpetuação da contratação; integração social na empresa, constitucionalismo, trabalho e o contexto de vida e relevância social do trabalho desenvolvido. ${ }^{11}$

Também designado psicoterror ou violência psicológica é causado pela precariedade nas condições de trabalho a que estão submetidos os empregados e se definem pela flexibilização da legislação, por diversos fatores econômicos, nível de desemprego, terceirização, aumento da informalidade e concorrência entre os empregados. O assédio se caracteriza pela abusividade das condutas praticadas por comportamentos, palavras, atos e escritos. O objetivo do assediador é desmoralizar o assediado, desestabilizando-o emocional e moralmente. ${ }^{12}$

Difere-se assédio moral de dano moral porque o primeiro é o ato praticado pelo assediador, proposital ou não, que gera um dano no assediado.

As pessoas mais suscetíveis de sofrerem assédio moral são as que por algum motivo fogem do padrão pré-estabelecido pela sociedade. ${ }^{13}$

Embora haja dissenso sobre o efeito da variável "gênero" sobre o assédio moral, Valadão Júnior e Mendonça afirmam existir divisão sexual no assédio moral, sendo as mulheres as maiores vítimas, incluindo o assédio sexual como um afronta moral. Neste caso, o assédio sexual é a violência física ou psíquica praticada pelo assediador contra a empregada com o objetivo que obter vantagens ou favores

\footnotetext{
11 CAMPOS, Maria Isabel de. RUEDA, Fabián Javier Marín. Assédio moral: evidências de validade de escala e relações com qualidade de vida no trabalho. Avaliação Psicológica, São Paulo, v. 15, n. 1 1, p. 21-30. 2016. Disponível em: http://pepsic.bvsalud.org/scielo.php?script=sci_abstract\&pid=S1677-04712016000100004. Acesso em: 02/02/2018. p. 23.

12 CAHÚ, Graziela Ribeiro Pontes. Et. Al. Assédio moral: análise de conceito na perspectiva evolucionista de Rodgers. Acta Paul Enferm., São Paulo, v. 25, n. 4, p. 555-559. 2012. Disponível em: http://www.scielo.br/scielo.php?pid=S0103-21002012000400012\&script=sci_abstract. Acesso em: 12/02/2018. p. 556-557.
}

13 ANTUNES, Bruna Meurer. CARLOTTO, Mary Sandra. STREY, Marlene Neves. Mulher e trabalho: visibilizando o tecido e a trama que engendram o assédio. Psicologia em Revista, Belo Horizonte, v. 18, n. 3, p. 420-445. dez. 2012. Disponível em: http://pepsic.bvsalud.org/scielo.php?script=sci_arttext\&pid=S1677-11682012000300006. Acesso em: 10/02/2018. p. 422. 
KERSTEN, Giselle Meira; FERREIRA, Marcelo Gitirana Gomes; ALVES, Paulo Roberto Ramos. Danos morais às mulheres nas relações de trabalho. Revista Eletrônica Direito e Política, Programa de PósGraduação Stricto Sensu em Ciência Jurídica da UNIVALI, Itajaí, v.14, n.1, 10 quadrimestre de 2019. Disponível em: www.univali.br/direitoepolitica - ISSN 1980-7791

sexuais por sua condição de subordinação ao emprego. Afirmam que a idade do empregado é também motivo de assédio. ${ }^{14}$

O assédio moral caracteriza-se pela submissão do trabalhador a constantes humilhações e constrangimentos. Expressa-se em atitudes violentas que provocam repercussões negativas na pessoa assediada, ferindo sua dignidade e infringindo seus direitos fundamentais. No Brasil, pesquisa realizada em 97 empresas no Estado de São Paulo, totalizando 2.072 entrevistados, percebeu-se que $42 \%$ dos entrevistados confirmaram ter passado por situações de humilhação no trabalho, mais comuns entre as mulheres. Os negros também são vítimas de assédio, além dos homossexuais, os portadores de necessidades especiais, os trabalhadores acima de 40 anos e os portadores de lesão por esforços repetitivos. Para que se configure o assédio necessário que haja ato abusivo ou agressivo; a repetição, a frequência, a duração destas práticas hostis; a intenção do assediador. ${ }^{15}$

O assédio pode ocorrer de forma ascendente, descendente, horizontal ou misto. $\mathrm{O}$ assédio ascendente ocorre quando um superior hierárquico comete atos de violência física ou psíquica contra um subordinado; o descendente que é o menos comum, é quando um subordinado assedia seu superior e o misto quando há assédio entre os dois, ou seja, o assediador é assediado também. Há quem defenda que o assédio pode ser horizontal, ou ainda, pessoas que ocupam mesmas funções ou estão no mesmo patamar hierárquico o praticam contra seus pares. A manutenção do emprego é a justificativa da vítima para submissão à condição de assédio. ${ }^{16}$

\footnotetext{
14 VALADÃO JÚNIOR, Valdir Machado. MENDONÇA, Juliana Moro Bueno. Assédio moral no trabalho: dilacerando oportunidades. p. 28-30.

15 BOBROFF, Maria Cristina Cescatto. MARTINS, Júlia Trevisan. Assédio moral, ética e sofrimento no trabalho. Rev. bioét. (Impr.), Brasília, v. 21, n. 2, p. 251-258, 2013. Disponível em: http://www.scielo.br/pdf/bioet/v21n2/a08v21n2.pdf. Acesso em: 20/02/2018. p. 253.

16 VALADÃO JÚNIOR, Valdir Machado. MENDONÇA, Juliana Moro Bueno. Assédio moral no trabalho: dilacerando oportunidades. p. 33.
} 
KERSTEN, Giselle Meira; FERREIRA, Marcelo Gitirana Gomes; ALVES, Paulo Roberto Ramos. Danos morais às mulheres nas relações de trabalho. Revista Eletrônica Direito e Política, Programa de PósGraduação Stricto Sensu em Ciência Jurídica da UNIVALI, Itajaí, v.14, n.1, 10 quadrimestre de 2019. Disponível em: www.univali.br/direitoepolitica - ISSN 1980-7791

O termo assédio moral é designado como violência no âmbito do trabalho e é um processo multicausal. ${ }^{17}$

São causas do assédio: "ciúme profissional" ou a inveja, temor do agressor que o agredido seja uma ameaça profissional constante e pela distinção de sexo, orientação sexual, cultura, nível de escolaridade, entre outros. ${ }^{18}$

Os impactos do sofrimento moral são perceptíveis na saúde do trabalhador e consequentemente, seu desempenho leva a um menor rendimento no trabalho, perda de possíveis oportunidades de ascensão profissional e à necessidade de ele se licenciar ou abandonar o emprego, e sobre este aspecto, muitas vezes é verdadeiramente o objetivo do assediador, fazer com que o assediado não tenha outra reação além de desistir de seu emprego. O assédio ultrapassa o ambiente de trabalho e afeta a sua vida pessoal, familiar e social do trabalhador. ${ }^{19}$

O desacato ao assediado causa sensação de incapacidade afetando sua vida profissional e pessoal. Desta forma, seu rendimento para o trabalho diminui e sua satisfação também se verificando a possibilidade de o empregado mudar de emprego. Um empregado assediado influencia negativamente outros empregados trazendo sensações de medo, desconfiança e raiva para o ambiente de trabalho. O custo destes atos é a redução da produtividade, afastamentos por motivos de doenças psíquicas e físicas e aumento dos custos para tratamento médico. ${ }^{20}$

Verifica-se também como consequências do assédio o acometimento de dores de cabeça, dores de estômago, insônia e tontura. Ansiedade, depressão também são consequências dos atos de assédio. O estresse pós-traumático apresentado por

17 SOARES, Angelo. As origens do conceito de assédio moral no trabalho. Rev. bras. Saúde ocup., São Paulo, v. 37, n. 126, p. 284-286. 2012. Disponível em: http://www.scielo.br/scielo.php?script=sci_arttext\&pid=S0303-76572012000200009. Acesso em: 02/02/2018. p. 285.

18 VALADÃO JÚNIOR, Valdir Machado. MENDONÇA, Juliana Moro Bueno. Assédio moral no trabalho: dilacerando oportunidades. p.23.

19 PINTO, Renata de Almeida Bicalho. PAULA, Ana Paula Paes de. Do assédio moral à violência interpessoal: Relatos sobre uma empresa júnior. p. 346.

20 VALADÃO JÚNIOR, Valdir Machado. MENDONÇA, Juliana Moro Bueno. Assédio moral no trabalho: dilacerando oportunidades. p.36. 
KERSTEN, Giselle Meira; FERREIRA, Marcelo Gitirana Gomes; ALVES, Paulo Roberto Ramos. Danos morais às mulheres nas relações de trabalho. Revista Eletrônica Direito e Política, Programa de PósGraduação Stricto Sensu em Ciência Jurídica da UNIVALI, Itajaí, v.14, n.1, 10 quadrimestre de 2019. Disponível em: www.univali.br/direitoepolitica - ISSN 1980-7791

pessoas que sofreram assédio moral nas relações de trabalho causa problemas de memória, dificuldade de concentração e insegurança. ${ }^{21}$

Estas pressões de ordem psicológica podem resultar tanto em danos psíquicos quanto físicos. Estas situações decorrem tanto de atitudes sádicas ou masoquistas por parte do assediador quanto pela rivalidade abusiva por rivalidade entre pares. O temor pela possibilidade de perda do emprego submete os empregados à aceitação desta condição. ${ }^{22}$

\section{EMPREGADAS COMO ALVO DOS ASSÉDIOS MORAIS}

Como já mencionado, as mulheres são mais assediadas moralmente e, por esta razão, far-se-á uma análise evolutiva da função da mulher e da trabalhadora para se entender melhor esta relação de submissão que casa danos muitas vezes irreparáveis.

Atribui-se à agricultura o fim da igualdade dos gêneros, deixando de lado a caça e a pesca, na qual ambos os sexos trabalhavam como iguais para sobrevivência. ${ }^{23}$

As sociedades patriarcais consideravam os homens como se criaturas superiores fossem, tanto que cabia exclusivamente à mulher atribuições domésticas, sendo severamente punidas pelo Código de Hamurabi, caso não cumprissem com suas obrigações a contento. Algumas civilizações patriarcais proibiam mulheres de terem propriedades; admitiam que os homens tivessem várias mulheres desde que as sustentassem; prezavam pelo nascimento de filhos homens, eliminando-se fetos ou crianças do sexo feminino como forma de controle da natalidade; quebravam ossos das mulheres chinesas para que não tivessem mobilidade,

${ }^{21}$ SOARES, Angelo. OLIVEIRA, Juliana Andrade. Assédio moral no trabalho. Rev. bras. Saúde ocup., São Paulo, v. 37, n. 126, p. 195-202. 2012. Disponível em: http://www.scielo.br/pdf/rbso/v37n126/a02v37n126.pdf. Acesso em: 18/01/2018. p. 197.

22 FAIMAN, Carla Júlia Segre. A queixa de assédio moral no trabalho e na psicoterapia. p. 128.

23 STEARNS, Peter N. História das relações de gênero. São Paulo: Contexto, 2007. p. 16. 
KERSTEN, Giselle Meira; FERREIRA, Marcelo Gitirana Gomes; ALVES, Paulo Roberto Ramos. Danos morais às mulheres nas relações de trabalho. Revista Eletrônica Direito e Política, Programa de PósGraduação Stricto Sensu em Ciência Jurídica da UNIVALI, Itajaí, v.14, n.1, 10 quadrimestre de 2019. Disponível em: www.univali.br/direitoepolitica - ISSN 1980-7791

restringindo assim a possibilidade de cometerem adultério ou abandonarem seus lares. ${ }^{24}$

Aristóteles afirmava a inferioridade da mulher em relação ao homem, tanto que o útero feminino era considerado um receptáculo vazio e inerte e somente gerava um novo ser humano porque recebia um sêmen masculino. ${ }^{25}$

Surge o movimento feminista, baseado em preceitos como a liberdade e a igualdade, em especial, relacionada ao direito ao trabalho e nas mesmas condições a que os homens estavam expostos. ${ }^{26}$

A crise da família e do casamento, que antes era concebido para aumento dos membros da família e com isto, maior domínio sobre as propriedades, passou a ser forma de união de pessoas pelas afinidades e afetos. Surge, a partir daí a denominada "divisão sexual do trabalho". Esta nova concepção familiar gerou, no mundo contemporâneo, mudanças de valores, estilos de vida. ${ }^{27}$

As máquinas foram substituindo trabalhos executados por mulheres e as pertencentes às classes mais baixas foram alvo de contratações pelas próprias indústrias, cujos salários pagos eram inferiores aos dos homens. ${ }^{28}$

A contratação de mulheres para o trabalho no período de guerra deu-se em virtude da necessidade de mão-de-obra nas indústrias enquanto os homens estavam envolvidos com os afazeres da guerra e por necessidade de manutenção das

24 VAITSMAN, Jeni. Gênero, identidade, casamento e família na sociedade contemporânea. In: Mulher, gênero e sociedade. MURARO, Rose Marie (Org.). Relume Dumará. Rio de Janeiro. p. 1314.

25 MURARO, Rose Marie. A Mulher no terceiro milênio: uma história da mulher através dos tempos e suas perspectivas para o futuro. 3. ed. Rio de Janeiro: Rosa dos Tempos, 1993. p. 91.

26 VAITSMAN, Jeni. Gênero, identidade, casamento e família na sociedade contemporânea. p. 16.

27 VAITSMAN, Jeni. Gênero, identidade, casamento e família na sociedade contemporânea. p. 16-17.

28 OLIVEIRA, João Mateus Silva Fagundes. FURTADO, Natália Maria Reis Oliveira. Mulher e trabalho: Igualdade material e formal - Uma utopia necessária. Revista Thesis Juris, São Paulo, v.3, n.1, p. 75-91. jan./jun. 2014. p. 82-83. 
KERSTEN, Giselle Meira; FERREIRA, Marcelo Gitirana Gomes; ALVES, Paulo Roberto Ramos. Danos morais às mulheres nas relações de trabalho. Revista Eletrônica Direito e Política, Programa de PósGraduação Stricto Sensu em Ciência Jurídica da UNIVALI, Itajaí, v.14, n.1, 10 quadrimestre de 2019. Disponível em: www.univali.br/direitoepolitica - ISSN 1980-7791

famílias. Embora pareça uma conquista, sua introdução no mercado de trabalho, para outros, serviu mais ao mercado do que aos interesses das mulheres. ${ }^{29}$

Sandra Bem apud Nogueira ${ }^{30}$ identifica três grandes crenças sociais: a de que homens e mulheres tem naturezas psicológicas e sexuais distintas; a que os homens são superiores e dominantes pois as mulheres seriam suas cópias "defeituosas" e que a natureza e a superioridade masculina são naturais.

Como homens e mulheres assumiram papéis diferenciados na sociedade, adquiriram competências e crenças distintas, resultando em diversidade de comportamentos. ${ }^{31}$

Neste contexto, a empregabilidade feminina pode ser afetada por diversos fatores influenciando na contratação, manutenção dos seus empregos e ascensão profissional. Passa-se, portanto, à elucidação de alguns destes fatores.

Verifica-se que a legislação trabalhista brasileira, em referência ao objeto deste estudo, criou normas protetivas, dada a possibilidade de a mulher sofrer discriminação no mercado de trabalho ou pela necessidade de proteção por sua condição física, social ou fatores culturais.

A ocupação do mercado de trabalho pelas mulheres e a cumulação de atribuições domésticas decorreu da necessidade da busca por melhores condições de vida e bem-estar familiar além do reconhecimento de utilidade social pelo trabalho desenvolvido fora do âmbito familiar. Segundo dados do IBGE, de 2013, mulheres passaram a ter funções de 26 horas semanais dedicadas às atividades domésticas enquanto que homens dedicam-se, em média, somente 11 horas. Este fator é

\footnotetext{
${ }^{29}$ KOLBENSCHLAG, Madonna. Adeus, Bela Adormecida. A revisão do papel da mulher nos dias de hoje. Tradução de Maria Silvia Mourão Netto. São Paulo: Saraiva, 1990. p. 118-120.

30 NOGUEIRA, Conceição. Um novo olhar sobre as relações sociais de gênero: Feminismo e perspectivas críticas na psicologia social. Braga: Fundação Calouste Gulbenkian, 2001. p. 185.

${ }^{31}$ NOGUEIRA, Conceição. Um novo olhar sobre as relações sociais de gênero: Feminismo e perspectivas críticas na psicologia social. p. 166.
} 
KERSTEN, Giselle Meira; FERREIRA, Marcelo Gitirana Gomes; ALVES, Paulo Roberto Ramos. Danos morais às mulheres nas relações de trabalho. Revista Eletrônica Direito e Política, Programa de PósGraduação Stricto Sensu em Ciência Jurídica da UNIVALI, Itajaí, v.14, n.1, 10 quadrimestre de 2019. Disponível em: www.univali.br/direitoepolitica - ISSN 1980-7791

relevante para se entender que muitas vezes a dedicação ao trabalho fora de casa fica prejudicado. 3233

Bruschini e Lombardi, apud Brites ${ }^{34}$, denominam o trabalho doméstico desenvolvidos pelas mulheres de "polo da precariedade", dadas as restrições impostas à função de "cuidar" atribuído às mulheres. Nos Estados Unidos, o desaparecimento do trabalho subordinado doméstico foi decorrente do desenvolvimento tecnológico, razão da fuga deste trabalho para o mercado aberto. Este trabalho destinado às mulheres fora de seus âmbitos domésticos é uma extensão do sistema patriarcal, no qual à mulher é imposta a obrigação de exercer trabalho remunerado, mas por falta de qualificação impõe-se a prática desta atividade que detém domínio. ${ }^{35}$

A separação de atividades econômicas entre homens e mulheres cria estereótipos com graves consequências. Esta divisão de tarefas integra-se em três aspectos: manifestações culturais, consenso entre os membros da sociedade, manutenção da cultura da função do líder. Salientam Medeiros e Valadão ${ }^{36}$, em suas pesquisas denominada "Masculinidade e Feminilidade nas Ameas: holograma, ilhas de clareza ou uma selva desconhecida?", que as organizações fazem divisão sexual do trabalho dando aos homens maiores responsabilidades e cargos mais relevantes subordinando mulheres em suas funções e com isto, o homem faz um controle direto do trabalho exercido por sua subordinada.

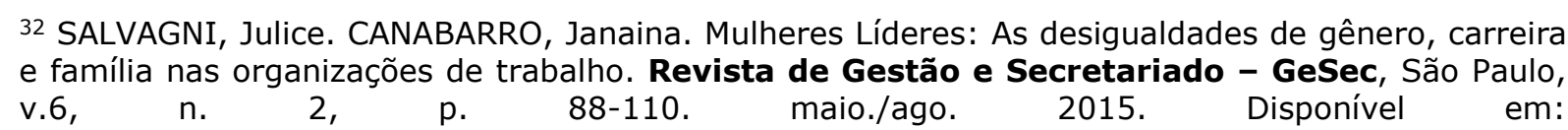
https://www.revistagesec.org.br/secretariado/article/view/347. Acesso em: 25/02/2018. p. 95-99.

33 IPEA - Instituto de Pesquisa Econômica Aplicada. Oferta de creche e participação das mulheres no mercado de trabalho no Brasil. In: Mercado de Trabalho: conjuntura e análise. Ano 23, abril 2017. Disponível em:

http://www.ipea.gov.br/portal/images/stories/PDFs/mercadodetrabalho/170505_bmt_62.pdf. Acesso em: 05/10/2017. p. 28-32.

34 BRITES, Julia. Serviço doméstico: Um outro olhar sobre a subordinação. In: Gênero, cultura e poder. LISBÔA, Maria Regina Azevedo. MALUF. Sônia Weidner. (Orgs.) Florianópolis: Mulheres, 2004. p. 111.

${ }^{35}$ COSTA, Suely Gomes. Saúde, gênero e representações sociais. In: Mulher, gênero e sociedade. MURARO, Rose Marie (Org.). Rio de Janeiro: Relume Dumará, 2001. p.120.

36 MEDEIROS, Cintia Rodrigues de Oliveira. VALADÃO Jr., Valdir Machado. Masculinidade e feminilidade na Ameas: holograma, ilhas de clareza ou uma selva desconhecida?. Cad. EBAPE.BR, Rio de Janeiro, v. 9, n. 1, artigo 5, p. 79-96. mar. 2011. p. 89. 
KERSTEN, Giselle Meira; FERREIRA, Marcelo Gitirana Gomes; ALVES, Paulo Roberto Ramos. Danos morais às mulheres nas relações de trabalho. Revista Eletrônica Direito e Política, Programa de PósGraduação Stricto Sensu em Ciência Jurídica da UNIVALI, Itajaí, v.14, n.1, 10 quadrimestre de 2019. Disponível em: www.univali.br/direitoepolitica - ISSN 1980-7791

Androcentrismo ou também denominado sexismo, são termos utilizados atualmente para definir ou explicar a secção de atividades laborais enquadradas como mais adequadas aos homens e às mulheres. Aduz-se que são formas de violência moral e sexual "legitimada pela lógica do gênero". O sexismo instrumental reduz a situação da mulher pela suposta incapacidade intelectual e supremacia dos seus dotes físicos e o sexismo automático dirigido ao gênero mulher. ${ }^{37}$

O ingresso das mulheres no mercado de trabalho não diminuiu as desigualdades profissionais entre os sexos. Elucida, sobre o tema, Melo ${ }^{38}$, afirmando que o emprego feminino ainda se mantém concentrado em certas atividades, restrito a algumas profissões, responsável pela desigualdade de condições de homens e mulheres no mercado de trabalho. A ausência de definição de profissão às mulheres faz com que aceitem sua participação no mercado de trabalho com apenas algumas ocupações pouco definidas e especializadas.

Para melhor elucidar esta questão, em 2009, segundo Carvalho39, as mulheres ocupavam $41,7 \%$ dos empregos formais para médicos, $50 \%$ para advogados, $47 \%$ dos empregos para procuradores e advogados públicos, $37 \%$ dos postos de magistrados, $41 \%$ dos membros do ministério público e $56 \%$ dos empregos formais para arquitetos e somente $16 \%$ dos empregos formais para engenheiros, no Brasil. Apresenta-se ainda, como atividades predominantemente femininas os "serviços de beleza" com 97,2\% de ocupação, atividades de educação com 92,3\%, secretariado e Trabalhos de Escritório com 91,2\%, serviço social e orientação com 91,0\%, ciências domésticas com 89,4\%, terapia e reabilitação com 84,5\%, enfermagem e atenção primária com $84,4 \%$, psicologia com $81,1 \%$, biologia e

37 LIMA, Betina Stefanello. O labirinto de cristal: as trajetórias das cientistas na Física. Estudos Feministas, Florianópolis, v. 21, n. 3, p. 883-903, set./dez. 2013. Disponível em: http://www.scielo.br/scielo.php?script=sci_abstract\&pid=S0104026X2013000300007\&lng=pt\&nrm=iso. Acesso em: 05/02/2018. p. 890.

38 MELO, Hildete Pereira. $O$ feminino nas manufaturas brasileiras. In: Mulher, gênero e sociedade. MURARO, Rose Marie (Org.). Rio de Janeiro: Relume Dumará, 2001. p. 124.

39 CARVALHO, Rutineia Oliveira. Sociedade, Mulher e profissão. Revista de Gestão e Secretariado - GeSec, São Paulo, v. 7, n. 1, p. 27-44. jan./abr. 2016. Disponível em: https://www.revistagesec.org.br/secretariado/article/view/396. Acesso em: 03/02/2018. p. 38. 
KERSTEN, Giselle Meira; FERREIRA, Marcelo Gitirana Gomes; ALVES, Paulo Roberto Ramos. Danos morais às mulheres nas relações de trabalho. Revista Eletrônica Direito e Política, Programa de PósGraduação Stricto Sensu em Ciência Jurídica da UNIVALI, Itajaí, v.14, n.1, 10 quadrimestre de 2019. Disponível em: www.univali.br/direitoepolitica - ISSN 1980-7791

bioquímica com 71,5\%, além de farmácia com 71,3\%. Estes dados refletem o sexismo no mercado de trabalho e reforça o paradigma das profissões femininas.

As batalhas permanentes das trabalhadoras pela conquista do direito de se introduzir e se manter no mercado de trabalho na condição de empregadas são registradas pela história como uma das mais dignas. Responsáveis pela manutenção dos valores educacionais, morais, éticos, religiosos, a quem a sociedade patriarcal atribui quase que exclusivamente esta função às mulheres, ainda são incumbidas de prover ou auxiliar no sustento da família. Fora estas obrigações sociais, as mulheres adquirem o direito de, proverem o sustento delegando poderes aos homens de executar tarefas dantes consideradas exclusivamente femininas como o resguardo das necessidades basilares da família.

As grandes dificuldades elencadas para a ascensão profissional da mulher são decorrentes de discriminação e preconceitos no ambiente profissional, dificuldade de acesso à algumas atividades pelo sexismo e os conflitos inerentes à dupla jornada de trabalho, doméstico e no emprego. ${ }^{40}$

A errônea concepção de que mulheres são mais dedicadas às atividades domésticas limita a capacidade dos homens em crer na capacidade progressiva das posições hierárquicas possíveis de serem assumidas pelas mesmas dentro de uma organização. A liderança se faz com habilidade independentemente do sexo do líder e o líder é aquele que tem a capacidade de influenciar modos de agir utilizando-se do seu poder de direção, encorajamento, sensibilidade, consideração e apoio. ${ }^{41}$

A distinção entre sexos, homem e mulher, pode ser análise de estudo social, político, trabalhista, psicológico, ou seja, discussão presente em diversas ciências sociais e humanas. A diferença de sexo constitui-se na predileção de papéis sociais

\footnotetext{
40 NOGUEIRA, Elaine Cristina Oliveira Rocha. KUBO, Edson Keyso de Miranda. Sentidos do exercício da liderança por mulheres executivas brasileiras. Revista de Gestão e Secretariado - GeSec, São Paulo, v. 4, n. 2, p 114-133. jul./dez. 2013. Disponível em: https://www.revistagesec.org.br/secretariado/article/view/175. Acesso em: 10/02/2018. p. 117.

${ }^{41}$ SALVAGNI, Julice. CANABARRO, Janaina. Mulheres Líderes: As desigualdades de gênero, carreira e família nas organizações de trabalho. p. 95.
} 
KERSTEN, Giselle Meira; FERREIRA, Marcelo Gitirana Gomes; ALVES, Paulo Roberto Ramos. Danos morais às mulheres nas relações de trabalho. Revista Eletrônica Direito e Política, Programa de PósGraduação Stricto Sensu em Ciência Jurídica da UNIVALI, Itajaí, v.14, n.1, 10 quadrimestre de 2019. Disponível em: www.univali.br/direitoepolitica - ISSN 1980-7791

e culturais diferentemente observáveis nas diversas partes do mundo. A distribuição de papéis sociais pode ser uma das causas geradoras de normativas que tanto protegem quanto discriminam o sexo feminino, que, inicialmente, por sua condição física, necessita de maior amparo inclusive legal.

Dentro deste contexto, verifica-se que vários são os fatores que ainda restringem o acesso das mulheres ao mercado de trabalho e são eles: preconceito, acordos familiares, restrições de trabalhos pela proteção da legislação em face das limitações físicas das mulheres e, em decorrência da maternidade e necessidade de afastamento do trabalho no período pós-parto.

Em decorrência destes fatores que indicam a discriminação da mulher no mercado de trabalho, extrai-se justificativas para que sejam alvos de assédio moral por parte dos seus empregadores e prepostos.

\section{METODOLOGIA}

Inicialmente foi realizada uma pesquisa na base de dados presentes nos periódicos da CAPES para atribuindo-se os termos "moral" e "mulher" e, posteriormente, "moral" e "trabalho". A pesquisa restringiu-se à busca por artigos eliminando-se as demais publicações. Na primeira pesquisa o período foi limitado aos últimos 5 anos, a contar do mês de outubro de 2018, obtendo-se como resultados 514 artigos, dos quais somente 24 artigos eram relacionados ao tema em análise. $\mathrm{Na}$ segunda parte da pesquisa, limitou-se à análise por um período de um ano e obteve-se 137 artigos, mas foram utilizados somente 4. Partiu-se para a pesquisa na base de dados Scielo e utilizou-se dos mesmos parâmetros anteriormente citados. Para a primeira pesquisa foram selecionados 82 artigos, porém somente 5 eram relacionados ao tema em foco e para a segunda parte da pesquisa, utilizando-se também os últimos cinco anos foram encontrados 243 artigos e utilizados 23.

Os demais artigos não utilizados foram descartados por não corresponderem ao objeto da pesquisa. Esta análise bibliométrica foi utilizada para fins de pesquisa de natureza qualitativa. 
KERSTEN, Giselle Meira; FERREIRA, Marcelo Gitirana Gomes; ALVES, Paulo Roberto Ramos. Danos morais às mulheres nas relações de trabalho. Revista Eletrônica Direito e Política, Programa de PósGraduação Stricto Sensu em Ciência Jurídica da UNIVALI, Itajaí, v.14, n.1, 10 quadrimestre de 2019. Disponível em: www.univali.br/direitoepolitica - ISSN 1980-7791

Finda esta pesquisa nas bases de dados, na forma elucidativa e explicativa, colacionou-se decisões do Egrégio Tribunal Regional do Trabalho da $12^{a}$ Região, cuja competência jurisdicional abrange o estado de Santa Catarina. Buscou-se decisões judiciais proferidas entre 01/01/2017 a 26/10/208, que reconheceram a ocorrência do dano moral aos empregados e condenaram seus empregadores ao pagamento de indenização. Considerou-se como reconhecido o dano sujeito à condenação tanto pela confirmação da sentença quanto pela condenação em segundo grau. Da mesma forma, a exclusão da condenação, contrariando a sentença proferida pelo $1^{0}$ grau de jurisdição foi entabulada como não reconhecimento da existência do dano capaz de ser reparado por indenização.

Utilizando-se os termos "moral" e "assédio" foram encontrados 367 acórdãos, sendo que destes, 27 foram descartados da análise por terem sido extintos sem resolução do mérito.

\section{RESULTADOS}

Após análise de todos os artigos fez-se leitura e seleção dos autores mais relevantes para o tema e são: Santos (2014); Ramos (2015); Closs, Oliveira (2015); Couto, Gomes (2012); Mattar, Diniz (2012); Pinsky, Pedro (2013); Silva (2013); Schraiber (2012); Nascimento (2013); Almeida, Elias (2014); Faiman (2016); Campos, Rueda (2016); Miguel, Biroli (2016); Soares (2012); Cahú, Leite, nóbrega, Fernandes, Costa, Costa (2012); Lima, Barbosa, Mendes, Patta (2014); Rodrigues, Freitas (2014); Valadão Jr. e Mendonça (2015); Soares, Oliveira (2012); Bobroff, Martins (2013); Pinto, Paula (2013); Schlindwein (2013); Glina, Soboll (2012); Silva, Raichelis (2015); Meurer, Strey (2012); Carrieri, Aguiar, Diniz (2013).

Com relação à pesquisa bibliométrica realizada percebeu-se uma diversidade de autores tratando sobre o mesmo tema e com enfoques totalmente distintos. Alguns abordam moral e suas vertentes sob sua concepção mais filosófica, outros sob a ótica administrativa, social e alguns fazem abordagem jurídica. Estranhamento pouco se tem redigido sobre o tema dano moral em outras esferas que não a jurídica, que analisa os pormenores da ocorrência do dano, causas, 
KERSTEN, Giselle Meira; FERREIRA, Marcelo Gitirana Gomes; ALVES, Paulo Roberto Ramos. Danos morais às mulheres nas relações de trabalho. Revista Eletrônica Direito e Política, Programa de PósGraduação Stricto Sensu em Ciência Jurídica da UNIVALI, Itajaí, v.14, n.1, 10 quadrimestre de 2019. Disponível em: www.univali.br/direitoepolitica - ISSN 1980-7791

consequências, nexos causais e formas de reparação. Verifica-se que grande parte dos artigos indicados foram produzidos e publicados na área da saúde, em especial, pela psicologia. Esta constatação faz refletir tanto sobre os motivos e perfis do assediador quanto nos efeitos psicológicos do assediado após o trauma sofrido.

$\mathrm{Na}$ área organizacional, empresarial, pouco se explora sobre o tema, o que é uma grande preocupação tendo em vista que os fatos acontecem sem que dentro das próprias empresas adote-se medidas ou políticas de erradicação dos fatos que causem danos. Boa parte dos artigos e autores citados como referências da bibliometria realizada foram utilizados como bases teóricas para a realização deste artigo.

Analisando-se os julgados do Tribunal Regional do Trabalho da $12^{a}$ Região, classificou-se e agrupou-se as decisões em categorias relacionadas aos motivos dos danos morais alegados nas referidas demandas.

Desta forma, conforme Quadro 1, foram agrupadas as causas dos danos supostamente sofridos pelos empregados em oito categorias. Foram considerados como fatores categorizados como "Rigidez no ambiente de trabalho", os casos em que se verificou a ocorrência de doenças físicas e psiquiátricas pelo rigor excessivo sofrido pelo empregado e pelo assédio para pedido de demissão no ambiente de trabalho. A pressão para cumprimento de "Metas" foi considerada o segundo fator. O terceiro fator encontrado nas decisões analisadas foi o constrangimento dos empregados pela "Troca de uniforme/roupa na frente dos colegas". O "Dano Existencial" refere-se ao excesso de jornada de trabalho e restrição para gozo das férias. Como "Descumprimento das Obrigações Contratuais", registrou-se reclamações pelo não registro da condição de empregado em Carteira de Trabalho e Previdência Social e não pagamento dos demais direitos trabalhistas, incluindo atraso no pagamento dos salários e exercício de função diversa da contratada. "Discriminação" foi o termo utilizado para enquadrar as discriminações sofridas em razão de sexo, idade, raça, orientação sexual, gravidez e deficiência física. A "Humilhação" foi identificada pelo controle do uso do banheiro pelos empregadores, xingamentos por motivos de divergência religiosa, política; revista 
KERSTEN, Giselle Meira; FERREIRA, Marcelo Gitirana Gomes; ALVES, Paulo Roberto Ramos. Danos morais às mulheres nas relações de trabalho. Revista Eletrônica Direito e Política, Programa de PósGraduação Stricto Sensu em Ciência Jurídica da UNIVALI, Itajaí, v.14, n.1, 10 quadrimestre de 2019. Disponível em: www.univali.br/direitoepolitica - ISSN 1980-7791

íntima ou não do empregado e agressão física e rebaixamento. Por fim, utilizouse a categoria "Meio Ambiente de Trabalho" para designar a aludida falta de segurança no ambiente de trabalho, higiene e indenização prevista legalmente para transporte de valores".

Foram analisadas todas as decisões, individualmente, seccionando homens e mulheres e classificando tanto os motivos pelas categorias indicadas quando a incidência ou não da condenação ao pagamento da indenização correspondente. Obteve-se o seguinte Quadro 1 como resposta ao questionamento:

Quadro 1 - Condenações por assédio moral no ambiente de trabalho

\begin{tabular}{|c|c|c|c|c|c|}
\hline Ano & Categorias & $\begin{array}{l}\text { Homem } \\
\text { sim }\end{array}$ & $\begin{array}{l}\text { Homem } \\
\text { não }\end{array}$ & $\begin{array}{l}\text { Mulher } \\
\text { sim }\end{array}$ & $\begin{array}{l}\text { Mulher } \\
\text { não }\end{array}$ \\
\hline \multirow[t]{8}{*}{2018} & $\begin{array}{l}\text { Rigidez no ambiente de } \\
\text { trabalho }\end{array}$ & 1 & 6 & 9 & 5 \\
\hline & Metas & 3 & 10 & 8 & 8 \\
\hline & $\begin{array}{l}\text { Troca de uniforme/roupa na } \\
\text { frente dos colegas }\end{array}$ & 1 & & & 1 \\
\hline & Dano Existencial & & & & 1 \\
\hline & $\begin{array}{ll}\text { Descumprimento } & \text { das } \\
\text { Obrigações Contratuais } & \end{array}$ & & 1 & 1 & 1 \\
\hline & Discriminação & & & & 1 \\
\hline & Humilhação & 9 & 8 & 3 & 2 \\
\hline & Meio Ambiente de Trabalho & 1 & & & \\
\hline Total & & 15 & 25 & 21 & 19 \\
\hline & & & & & \\
\hline
\end{tabular}


KERSTEN, Giselle Meira; FERREIRA, Marcelo Gitirana Gomes; ALVES, Paulo Roberto Ramos. Danos morais às mulheres nas relações de trabalho. Revista Eletrônica Direito e Política, Programa de PósGraduação Stricto Sensu em Ciência Jurídica da UNIVALI, Itajaí, v.14, n.1, 10 quadrimestre de 2019. Disponível em: www.univali.br/direitoepolitica - ISSN 1980-7791

\begin{tabular}{|l|l|l|l|l|l|}
\hline 2017 & $\begin{array}{l}\text { Rigidez no ambiente de } \\
\text { trabalho }\end{array}$ & 8 & 22 & 15 & 26 \\
\hline & $\begin{array}{l}\text { Metas } \\
\text { frente dos colegas }\end{array}$ & 14 & 23 & 11 & 18 \\
\hline & $\begin{array}{l}\text { Dano Existencial } \\
\text { Obrigações Contratuais das }\end{array}$ & 2 & & 4 \\
\hline & $\begin{array}{l}\text { Descumprimento } \\
\text { Discriminação }\end{array}$ & 9 & 6 & 1 \\
\hline & $\begin{array}{l}\text { Humilhação } \\
\text { Total }\end{array}$ & 18 & 21 & 9 & 22 \\
\hline
\end{tabular}

Fonte: Criado pela autora.

Em 2018 verificou-se que o número de ingressos judiciais pleiteando condenação da empregadora ao pagamento de indenização por danos morais foi igual entre homens e mulheres. É nítido que o número de condenações do referido reparo para as mulheres foi maior do que o dos homens, sendo 21 condenações em favor das mulheres e 15 em favor dos homens. Chama a atenção o reconhecimento e consequente condenação ao pagamento da referida indenização pela rigidez no ambiente de trabalho a que estão submetidas as mulheres, em que de um total de 14 ações, foi reconhecido o direito em 9 delas, enquanto que para os homens, de um total de 7 ações, somente em 1 se reconheceu o rigor a que estão submetidos no tratamento por seus superiores. Assim como se evidencia o quanto as mulheres sofrem o rigor no ambiente de trabalho, da mesma forma que são cobradas mais pelo cumprimento de metas, em que as mulheres, de 16 demandas para reconhecimento do rigor do cumprimento de metas, em 8 ações foi 
KERSTEN, Giselle Meira; FERREIRA, Marcelo Gitirana Gomes; ALVES, Paulo Roberto Ramos. Danos morais às mulheres nas relações de trabalho. Revista Eletrônica Direito e Política, Programa de PósGraduação Stricto Sensu em Ciência Jurídica da UNIVALI, Itajaí, v.14, n.1, 10 quadrimestre de 2019. Disponível em: www.univali.br/direitoepolitica - ISSN 1980-7791

reconhecido o direito à indenização por danos morais e no caso dos homens, de 13 ações, somente 3 foi deferido o pedido.

Em 2017 verificou-se que predominaram as reclamações das empregadas com relação à rigidez com que são tratados no trabalho, sendo evidente o maior número de condenações ao pagamento de indenizações por danos morais, seguida das humilhações que passam. No primeiro caso, foram 41 demandas por mulheres, sendo reconhecido o direito à indenização em 15 dos pedidos e no caso dos homens, foram 30, sendo deferido o pedido somente em 8 deles. Com relação ao pedido de reparo pelo cumprimento exacerbado de metas, verificou-se uma proporcionalidade na qual foram 37 ações movidas pelos homens, tendo sido deferido o pedido em 14 delas e no caso das mulheres foram 29 ações e deferidas 11. Neste mesmo ano em análise, verifica-se que com relação ao pedido de reparo sob o argumento de discriminação, o que não foi evidenciado em 2018, foram 5 ações movidas pelos homens, reconhecendo-se o direito somente em 1 delas enquanto que no caso das mulheres foram 4 ações, reconhecendo-se o direito ao reparo em 3 delas. Com relação à humilhação sofrida no ambiente de trabalho, percebe-se que houve reconhecimento do direito ao reparo em quase metade de todas as ações movidas pelos homens, ou seja, num total de 39 ações, foi deferido o pedido indenizatório em 18 delas, enquanto que no caso das mulheres, de um total de 31 ações, foram reconhecidas as condições de humilhação somente em 9.

Os demais pedidos, embora catalogados no quadro, em razão da ausência de relevância das ações e condenações, não foram comentados.

Por fim, salutar que se destaque que grande parte dos indeferimentos foram decorrentes da ausência da prova dos empregados, a quem incumbia o ônus probatório.

A partir desta análise dos dados coletados, far-se-á a exposição de alguns julgados que deferiram o pedido de indenização por danos morais às empregadas, escolhidos dentre todos, os mais relevantes e condizentes com os resultados obtidos. 
KERSTEN, Giselle Meira; FERREIRA, Marcelo Gitirana Gomes; ALVES, Paulo Roberto Ramos. Danos morais às mulheres nas relações de trabalho. Revista Eletrônica Direito e Política, Programa de PósGraduação Stricto Sensu em Ciência Jurídica da UNIVALI, Itajaí, v.14, n.1, 10 quadrimestre de 2019. Disponível em: www.univali.br/direitoepolitica - ISSN 1980-7791

No Recurso Ordinário de no 0002619-36.2014.5.12.006, reformando a decisão de primeiro grau, entendeu por bem, a $1^{\text {a }}$ Câmara, condenar a empresa Ré ao pagamento de indenização por danos morais em razão do reconhecimento de que a atitude abusiva da empregadora na cobrança de metas, ameaças e uso de palavras de baixo calão, assediaram moralmente a empregada no curso do contrato de trabalho. E nestes termos, extrai-se parte do acórdão em que o MMo Julgador Relator assim frisa:

Entende-se por assédio moral da conduta abusiva da empresa ou do preposto, que atente, por sua repetição ou sistematização, contra a dignidade ou a integridade física ou psíquica do trabalhador. ${ }^{42}$

Em outra decisão proferida pela mesma $1^{a}$ Câmara, RO no 000296203.2013.5.12.0027 a empregada reclama a majoração do valor arbitrado na sentença de $1^{\circ}$ grau e a empresa condenada reclama pela exclusão da referida condenação ao pagamento de indenização por danos morais. Em análise ao caso em comento, verifica-se que a empregada era professora universitária e, em razão de eleições para novo reitor, sofreu pressão política e perseguição de seus superiores hierárquicos. A decisão proferida, sobre o dano moral assim se manifesta:

Assédio moral é a exposição de alguém a situações
humilhantes e constrangedoras, de forma repetitiva e
prolongada durante a jornada de trabalho e/ou no exercício
de suas funções. Trata-se de prática mais comum em relações
hierárquicas, nas quais predominam condutas negativas,
relações desumanas e antiéticas, dirigidas por um ou mais
chefes ou superior hierárquico em face de um ou mais
subordinados, desestabilizando a relação da vítima com o
ambiente de trabalho e a organização. São atitudes que,
repetidas com frequência, tornam insustentável a
permanência do empregado no emprego, causando danos. ${ }^{43}$

42 BRASIL. Tribunal Regional do Trabalho (12. Região). $1^{\text {a }}$ Câmara. Recurso Ordinário no 000261936.2014.5.12.0006. Recorrentes: Iara Cargnin Espíndula e Itaú Unibanco S.A. e outros. Recorridos: os mesmos. Relator: Desembargadora Viviane Colucci. Florianópolis, 20 de junho de 2018. Disponível em: http://www.trt12.jus.br/doe/visualizarDocumento.do?acao=doc\&acordao=true\&id=348920. Acesso em 26/10/2018. p. 29.

43 BRASIL. Tribunal Regional do Trabalho (12. Região). $1^{\text {a }}$ Câmara. Recurso Ordinário no $0002962-$ 03.2013.5.12.0027. Recorrentes: Fundação Educacional de Criciúma FUCRI - Universidade do Extremo Sul Catarinense - UNESC e Clélia Mara Fontanella Silveira. Recorridos: os mesmos. Relator: 
KERSTEN, Giselle Meira; FERREIRA, Marcelo Gitirana Gomes; ALVES, Paulo Roberto Ramos. Danos morais às mulheres nas relações de trabalho. Revista Eletrônica Direito e Política, Programa de PósGraduação Stricto Sensu em Ciência Jurídica da UNIVALI, Itajaí, v.14, n.1, 10 quadrimestre de 2019. Disponível em: www.univali.br/direitoepolitica - ISSN 1980-7791

Por fim, concluiu, a r. Decisão, pela manutenção da condenação, imputando-se a redução do valor dantes arbitrado, por entender que as provas produzidas nos autos suficientemente comprovaram que os abalos psicológicos sofridos pela empregada.

Em outra decisão, proferida pela $3^{a}$ Câmara, no RO no $0004717-$ 66.2015.5.12.0003, assim manifestou-se:

A caracterização do dano moral independe da demonstração de prejuízo, sendo suficiente a existência do ato gravoso à esfera íntima da vítima, uma vez que lhe causa diversas perturbações na tranquilidade, no conceito e na credibilidade que possui perante o meio social em que vive. ${ }^{44}$

No caso em análise, a empregada era fiscalizada no ambiente de trabalho sob o argumento que de vez em quando era vista "vadiando no trabalho". Por esta razão, pelo entendimento de que ofendeu a moral da empregada, manteve a decisão condenatória, reduzindo, somente o quantum deferido anteriormente.

A rigidez ou mais especificamente, a rigidez, com que a empregada era tratada por seus superiores hierárquicos restou cabalmente demonstrada nos autos do RO no 0000553-29.2015.5.12.0045 ${ }^{45}$, proferido pela 5a Câmara, em que se extrai dos autos, pelos depoimentos das testemunhas, que além do cumprimento de metas, utilizava palavras de baixo calão, ameaça agredir fisicamente, ridicularizava com piadas na frente de outros empregados. Em razão do meio ambiente de trabalho

Desembargador Wanderley Godoy Junior. Florianópolis, 14 de dezembro de 2017. Disponível em: http://www.trt12.jus.br/doe/visualizarDocumento.do?acao=doc\&acordao =true\&id $=344365$. Acesso em 26/10/2018. p. 5.

44 BRASIL. Tribunal Regional do Trabalho (12. Região). 3a Câmara. Recurso Ordinário no $0004717-$ 66.2015.5.12.0003. Recorrente: Plansul Planejamento e Consultoria Ltda.. Recorrido: Raimunda Elieuda Freitas da Silva Carvalho. Relator: Desembargador Gilmar Cavalieri. Florianópolis, 07 de fevereiro de 2018. Disponível em: http://www.trt12.jus.br/doe/visualizarDocumento.do?acao=doc\&acordao=true\&id $=344764$. Acesso em 26/10/2018. p. 8.

45 BRASIL. Tribunal Regional do Trabalho (12. Região). Recurso Ordinário no 000055329.2015.5.12.0045. Recorrentes: Caroline Silva de Paula - Banco Bradesco S.A.. Recorridos: os mesmos. Relator: Desembargadora Gisele Pereira Alexandrino. Florianópolis, 5 de junho de 2018. Disponível

em: http://www.trt12.jus.br/doe/visualizarDocumento.do?acao=doc\&acordao =true\&id=347376. Acesso em 26/10/2018. p. 6-9. 
KERSTEN, Giselle Meira; FERREIRA, Marcelo Gitirana Gomes; ALVES, Paulo Roberto Ramos. Danos morais às mulheres nas relações de trabalho. Revista Eletrônica Direito e Política, Programa de PósGraduação Stricto Sensu em Ciência Jurídica da UNIVALI, Itajaí, v.14, n.1, 10 quadrimestre de 2019. Disponível em: www.univali.br/direitoepolitica - ISSN 1980-7791

hostil, foi acometida de depressão, reconhecendo-se o nexo causal entre as condições de trabalho a que estava submetida e a doença apresentada.

Nos autos do RO no 0002063-92.2014.5.12.001946, julgado pela $1^{\text {a }}$ Câmara, a empregada comprova ter sofrido injúria racial através dos depoimentos de testemunhas que presenciaram empregados ironizando a reclamante pela cor da pele, pelo aspecto capilar, e insinuando que se parecia com um macaco. Houve condenação em juízo de primeiro grau, majorado o valor pelo juízo de segundo grau.

O assédio sexual, que afeta moralmente uma pessoa, restou comprovado no RO no 0001597-98.2015.5.12.0040, de cunho da 6a Câmara. Evidenciou-se o sofrimento da empregada e de outras através dos depoimentos, em que além dos superiores hierárquicos comentarem sobre as partes íntimas das empregadas e expressarem piadas com conotação sexual, insinuavam que o uso dos atributos corporais das mesmas auxiliaria as vendas. Desta forma, manifestou-se o julgado:

O assédio moral configura-se numa prática de gestão injuriosa, em que o superior hierárquico, através de uma conduta abusiva, atenta, por sua repetição ou sistematização, contra a dignidade ou a integridade psíquica ou física do trabalhador, deteriorando o ambiente de trabalho. O assédio sexual, por sua vez, fica configurado quando o superior, se aproveitando dessa condição inerente à sua posição dentro da empresa, tenta obter favorecimento de conotação sexual. ${ }^{47}$

46 BRASIL. Tribunal Regional do Trabalho (12. Região). $1^{\text {a }}$ Câmara. Recurso Ordinário no $0002063-$ 92.2014.5.12.0019. Recorrentes: Cristiane Antônia Ramos Batista e Zanotti S.A.. Recorridos: os mesmos. Relator: Desembargador José Ernesto Manzi. Florianópolis, 22 de fevereiro de 2017. Disponível

em:

http://www.trt12.jus.br/doe/visualizarDocumento.do?acao=doc\&acordao =true\&id $=334618$. Acesso em 26/10/2018. p. 19-23.

47 BRASIL. Tribunal Regional do Trabalho (12. Região). 6a Câmara. Recurso Ordinário no 000159798.2015.5.12.0040. Recorrentes: Optitel Redes e Telecomunicações Ltda. e Daiane Carine de Almeida. Recorridos: os mesmos. Relator: Desembargadora Teresa Regina Cotosky. Florianópolis, 15 de agosto de $2017 . \quad$ Disponível em: http://www.trt12.jus.br/doe/visualizarDocumento.do?acao=doc\&acordao =true\&id=340339. Acesso em 26/10/2018. p. 4. 
KERSTEN, Giselle Meira; FERREIRA, Marcelo Gitirana Gomes; ALVES, Paulo Roberto Ramos. Danos morais às mulheres nas relações de trabalho. Revista Eletrônica Direito e Política, Programa de PósGraduação Stricto Sensu em Ciência Jurídica da UNIVALI, Itajaí, v.14, n.1, 10 quadrimestre de 2019. Disponível em: www.univali.br/direitoepolitica - ISSN 1980-7791

Percebe-se, portanto, pelos acórdãos comentados, entre tantos outros, que comprovado o ato de assédio e o dano sofrido pelo empregado nas condições de trabalho a que está submetido, devido é o reparo através da condenação ao pagamento de indenização.

Com relação à pesquisa jurisprudencial, transcreve-se, pois, algumas das decisões referidas, dada a sua importância para a elucidação dos casos.

\section{CONSIDERAÇÕES FINAIS}

Do exposto extrai-se que é iminente a preocupação das empresas em observar fatos que podem gerar danos morais aos empregados e a criação de regras de conduta ou políticas administrativas para erradicar a possibilidade de submissão a situações que conduzam aos danos.

Pela análise bibliográfica percebe-se que, mesmo que seja uma demanda recorrente desde que admitida a reparação dos danos pela Constituição Federal de 1988, não há preparo por parte dos seus gestores a fim de evitar a ocorrência dos danos aos empregados.

Não há dúvida quanto à necessidade de proteção aos trabalhadores para que não sejam vítimas dos danos morais causados no meio ambiente de trabalho. São danos que podem afetar psicológica ou fisicamente, mas podem ser irreversíveis, inibindo que retornem ao mercado de trabalho e exerçam dignamente um direito fundamental que é a livre iniciativa do trabalho, garantia constitucional.

Os empregados ao causarem ou deixarem que causem danos aos empregados devem ser punidos e, em alguns casos, além da condenação ao pagamento de indenização virando reparar ou compensar o mal causado, podem sofrer sanções penais como nos casos do cometimento de agressões físicas, raciais ou ainda a submissão a condições não dignas de trabalho como em casos análogos a de escravos ou que apresentem risco iminente de morte. 
KERSTEN, Giselle Meira; FERREIRA, Marcelo Gitirana Gomes; ALVES, Paulo Roberto Ramos. Danos morais às mulheres nas relações de trabalho. Revista Eletrônica Direito e Política, Programa de PósGraduação Stricto Sensu em Ciência Jurídica da UNIVALI, Itajaí, v.14, n.1, 10 quadrimestre de 2019. Disponível em: www.univali.br/direitoepolitica - ISSN 1980-7791

Percebe-se que em muitos casos estudados o dano moral evidenciou-se mas por ausência de prova convincente, deixou, o TRT da $12^{a}$ Região, de reconhecê-lo e repará-lo com uma condenação ao pagamento da indenização devida e justa.

As empregadas, por serem consideradas mais fracas física e psicologicamente são alvos dos danos, em especial, como se demonstrou, pela necessidade de emprego, mas sofrendo discriminação por ser mulher e ter direitos garantidos por esta condição. Outros fatores de discriminação da mulher são a limitação por sua capacidade física e pela condição social a que sempre esteve submetida, como a subordinação social em comunidade patriarcal.

Portanto, realizar-se no trabalho é buscar o ethos grego, sem submissão a sofrimento desnecessário pelos empregados, cujo objetivo é o exercício pleno direito ao trabalho.

\section{REFERÊNCIAS DAS FONTES CITADAS}

ANTUNES, Bruna Meurer. CARLOTTO, Mary Sandra. STREY, Marlene Neves. Mulher e trabalho: visibilizando o tecido e a trama que engendram o assédio. Psicologia em Revista, Belo Horizonte, v. 18, n. 3, p. 420-445. dez. 2012. Disponível em: http://pepsic.bvsalud.org/scielo.php?script=sci_arttext\&pid=S167711682012000300006 . Acesso em: 10/02/2018.

BAKAN, Joel. A corporação. A busca patológica por lucro e poder. Tradução de Camila Werner. São Paulo: Novo Conceito Editora, 2008. 272 p.

BOBROFF, Maria Cristina Cescatto. MARTINS, Júlia Trevisan. Assédio moral, ética e sofrimento no trabalho. Rev. bioét. (Impr.), Brasília, v. 21, n. 2, p. 251-258, 2013. Disponível em: http://www.scielo.br/pdf/bioet/v21n2/a08v21n2.pdf. Acesso em: 20/02/2018.

BOFF, Leonardo. Ética e moral: a busca dos fundamentos. 4. ed. Petrópolis: Vozes, 2009. 125 p. 
KERSTEN, Giselle Meira; FERREIRA, Marcelo Gitirana Gomes; ALVES, Paulo Roberto Ramos. Danos morais às mulheres nas relações de trabalho. Revista Eletrônica Direito e Política, Programa de PósGraduação Stricto Sensu em Ciência Jurídica da UNIVALI, Itajaí, v.14, n.1, 10 quadrimestre de 2019. Disponível em: www.univali.br/direitoepolitica - ISSN 1980-7791

BRASIL. Tribunal Regional do Trabalho (12. Região). $1^{\text {a }}$ Câmara. Recurso Ordinário no 0002619-36.2014.5.12.0006. Recorrentes: Iara Cargnin Espíndula e Itaú Unibanco S.A. e outros. Recorridos: os mesmos. Relator: Desembargadora Viviane Colucci. Florianópolis, 20 de junho de 2018. Disponível em: http://www.trt12.jus.br/doe/visualizarDocumento.do?acao=doc\&acordao=true\&i $d=348920$. Acesso em 26/10/2018.

BRASIL. Tribunal Regional do Trabalho (12. Região). $1^{\text {a }}$ Câmara. Recurso Ordinário no 0002962-03.2013.5.12.0027. Recorrentes: Fundação Educacional de Criciúma FUCRI - Universidade do Extremo Sul Catarinense - UNESC e Clélia Mara Fontanella Silveira. Recorridos: os mesmos. Relator: Desembargador Wanderley Godoy Junior. Florianópolis, 14 de dezembro de 2017. Disponível em: http://www.trt12.jus.br/doe/visualizarDocumento.do?acao=doc\&acordao=true\&i $d=344365$. Acesso em 26/10/2018.

BRASIL. Tribunal Regional do Trabalho (12. Região). $3^{a}$ Câmara. Recurso Ordinário no 0004717-66.2015.5.12.0003. Recorrente: Plansul Planejamento e Consultoria Ltda.. Recorrido: Raimunda Elieuda Freitas da Silva Carvalho. Relator: Desembargador Gilmar Cavalieri. Florianópolis, 07 de fevereiro de 2018. Disponível em: http://www.trt12.jus.br/doe/visualizarDocumento.do?acao=doc\&acordao=true\&i $d=344764$. Acesso em 26/10/2018.

BRASIL. Tribunal Regional do Trabalho (12. Região). Recurso Ordinário no 0000553-29.2015.5.12.0045. Recorrentes: Caroline Silva de Paula - Banco Bradesco S.A.. Recorridos: os mesmos. Relator: Desembargadora Gisele Pereira Alexandrino. Florianópolis, 5 de junho de 2018. Disponível em: http://www.trt12.jus.br/doe/visualizarDocumento.do?acao=doc\&acordao=true\&i $d=347376$. Acesso em 26/10/2018.

BRASIL. Tribunal Regional do Trabalho (12. Região). $1^{\text {a }}$ Câmara. Recurso Ordinário no 0002063-92.2014.5.12.0019. Recorrentes: Cristiane Antônia Ramos Batista e Zanotti S.A.. Recorridos: os mesmos. Relator: Desembargador José Ernesto Manzi. Florianópolis, 22 de fevereiro de 2017. Disponível em: 
KERSTEN, Giselle Meira; FERREIRA, Marcelo Gitirana Gomes; ALVES, Paulo Roberto Ramos. Danos morais às mulheres nas relações de trabalho. Revista Eletrônica Direito e Política, Programa de PósGraduação Stricto Sensu em Ciência Jurídica da UNIVALI, Itajaí, v.14, n.1, 10 quadrimestre de 2019. Disponível em: www.univali.br/direitoepolitica - ISSN 1980-7791

http://www.trt12.jus.br/doe/visualizarDocumento.do?acao=doc\&acordao=true\&i $d=334618$. Acesso em 26/10/2018.

BRASIL. Tribunal Regional do Trabalho (12. Região). 6a Câmara. Recurso Ordinário no 0001597-98.2015.5.12.0040. Recorrentes: Optitel Redes e Telecomunicações Ltda. e Daiane Carine de Almeida. Recorridos: os mesmos. Relator: Desembargadora Teresa Regina Cotosky. Florianópolis, 15 de agosto de 2017. Disponível em: http://www.trt12.jus.br/doe/visualizarDocumento.do?acao=doc\&acordao=true\&i $d=340339$. Acesso em 26/10/2018.

BRITES, Julia. Serviço doméstico: Um outro olhar sobre a subordinação. In: Gênero, cultura e poder. LISBÔA, Maria Regina Azevedo. MALUF, Sônia Weidner (Orgs.). Florianópolis: Mulheres, 2004. p. 111-131.

CAHÚ, Graziela Ribeiro Pontes. Et. Al. Assédio moral: análise de conceito na perspectiva evolucionista de Rodgers. Acta Paul Enferm, São Paulo, v. 25, n. 4, p. 555-559. 2012. Disponível em: http://www.scielo.br/scielo.php?pid=S010321002012000400012\&script=sci_abstract. Acesso em: 12/02/2018.

CAMPOS, Maria Isabel de. RUEDA, Fabián Javier Marín. Assédio moral: evidências de validade de escala e relações com qualidade de vida no trabalho. Avaliação Psicológica, São Paulo, v. 15, n. 1, p. 21-30. 2016. Disponível em: http://pepsic.bvsalud.org/scielo.php?script=sci_abstract\&pid=S167704712016000100004 . Acesso em: 02/02/2018.

CARVALHO, Rutineia Oliveira. Sociedade, Mulher e profissão. Revista de Gestão e Secretariado - GeSec, São Paulo, v. 7, n. 1, p. 27-44. jan./abr. 2016. Disponível em: https://www.revistagesec.org.br/secretariado/article/view/396. Acesso em: 03/02/2018.

COSTA, Suely Gomes. Saúde, gênero e representações sociais. In: Mulher, gênero e sociedade. MURARO, Rose Marie (Org.). Rio de Janeiro: Relume Dumará, 2001. p.112-123. 
KERSTEN, Giselle Meira; FERREIRA, Marcelo Gitirana Gomes; ALVES, Paulo Roberto Ramos. Danos morais às mulheres nas relações de trabalho. Revista Eletrônica Direito e Política, Programa de PósGraduação Stricto Sensu em Ciência Jurídica da UNIVALI, Itajaí, v.14, n.1, 10 quadrimestre de 2019. Disponível em: www.univali.br/direitoepolitica - ISSN 1980-7791

FAIMAN, Carla Júlia Segre. A queixa de assédio moral no trabalho e na psicoterapia. Psicologia em Estudo, Maringá, v. 21, n. 1, p. 127-135. jan./mar. 2016. Disponível em: <http://periodicos.uem.br/ojs/index.php/PsicolEstud/article/view/28311>. Acesso em: 10/01/2018.

IPEA - Instituto de Pesquisa Econômica Aplicada. Oferta de creche e participação das mulheres no mercado de trabalho no Brasil. In: Mercado de Trabalho: conjuntura e análise. Ano 23, abril 2017. Disponível em: http://www.ipea.gov.br/portal/images/stories/PDFs/mercadodetrabalho/170505_ bmt_62.pdf. Acesso em: 05/10/2017.

KOLBENSCHLAG, Madonna. Adeus, Bela Adormecida. A revisão do papel da mulher nos dias de hoje. Tradução de Maria Silvia Mourão Netto. São Paulo: Saraiva, 1990. 315 p.

LIMA, Betina Stefanello. O labirinto de cristal: as trajetórias das cientistas na Física. Estudos Feministas, Florianópolis, v. 21, n. 3, p. 883-903, set./dez. 2013. Disponível em: http://www.scielo.br/scielo.php?script=sci_abstract\&pid=S0104026X2013000300007\&lng=pt\&nrm=iso. Acesso em: 05/02/2018.

MATOS, Francisco Gomes de. Ética na gestão empresarial, na conscientização à ação. São Paulo: Saraiva, 2008. 155 p.

MEDEIROS, Cintia Rodrigues de Oliveira. VALADÃO Jr., Valdir Machado. Masculinidade e feminilidade na Ameas: holograma, ilhas de clareza ou uma selva desconhecida? CADERNOS EBAPE.BR, Rio de Janeiro, v. 9, n. 1, artigo 5, p.7996. mar. 2011.

MELO, Hildete Pereira. O feminino nas manufaturas brasileiras. In: Mulher, gênero e sociedade. MURARO, Rose Marie (Org.). Rio de Janeiro: Relume Dumará, 2001. p.124-136.

MURARO, Rose Marie. A Mulher no terceiro milênio: uma história da mulher através dos tempos e suas perspectivas para o futuro. 3. ed. Rio de Janeiro: Rosa dos Tempos, 1993. 205 p. 
KERSTEN, Giselle Meira; FERREIRA, Marcelo Gitirana Gomes; ALVES, Paulo Roberto Ramos. Danos morais às mulheres nas relações de trabalho. Revista Eletrônica Direito e Política, Programa de PósGraduação Stricto Sensu em Ciência Jurídica da UNIVALI, Itajaí, v.14, n.1, 10 quadrimestre de 2019. Disponível em: www.univali.br/direitoepolitica - ISSN 1980-7791

NOGUEIRA, Conceição. Um novo olhar sobre as relações sociais de gênero: Feminismo e perspectivas críticas na psicologia social. Braga: Fundação Calouste Gulbenkian, 2001. p. 131-240.

NOGUEIRA, Elaine Cristina Oliveira Rocha. KUBO, Edson Keyso de Miranda. Sentidos do exercício da liderança por mulheres executivas brasileiras. Revista de Gestão e Secretariado - GeSec, São Paulo, v. 4, n. 2, p 114-133. jul./dez. 2013. Disponível em: https://www.revistagesec.org.br/secretariado/article/view/175. Acesso em: 10/02/2018.

OLIVEIRA, João Mateus Silva Fagundes. FURTADO, Natália Maria Reis Oliveira. Mulher e trabalho: Igualdade material e formal - Uma utopia necessária. Revista Thesis Juris, São Paulo, v. 3, n. 1, p. 75-91. jan./jun. 2014.

PINTO, Renata de Almeida Bicalho. PAULA, Ana Paula Paes de. Do assédio moral à violência interpessoal: Relatos sobre uma empresa júnior. Cad. EBAPE.BR, Rio de Janeiro, v. 11, n. 3, artigo 1. set./nov. 2013. Disponível em: http://bibliotecadigital.fgv.br/ojs/index.php/cadernosebape/article/view/7491. Acesso em: 05/05/2018.

SALVAGNI, Julice. CANABARRO, Janaina. Mulheres Líderes: As desigualdades de gênero, carreira e família nas organizações de trabalho. Revista de Gestão e Secretariado - GeSec, São Paulo, v. 6, n. 2, p 88-110. maio./ago. 2015. Disponível em: https://www.revistagesec.org.br/secretariado/article/view/347. Acesso em: 25/02/2018.

SOARES, Angelo. OLIVEIRA, Juliana Andrade. Assédio moral no trabalho. Rev. bras. Saúde ocup., São Paulo, v. 37, n. 126, p. 195-202. 2012. Disponível em: http://www.scielo.br/pdf/rbso/v37n126/a02v37n126.pdf. Acesso em: $18 / 01 / 2018$.

SOARES, Angelo. As origens do conceito de assédio moral no trabalho. Rev. bras. Saúde ocup., São Paulo, v. 37, n. 126, p. 284-286. 2012. Disponível em: 
KERSTEN, Giselle Meira; FERREIRA, Marcelo Gitirana Gomes; ALVES, Paulo Roberto Ramos. Danos morais às mulheres nas relações de trabalho. Revista Eletrônica Direito e Política, Programa de PósGraduação Stricto Sensu em Ciência Jurídica da UNIVALI, Itajaí, v.14, n.1, 10 quadrimestre de 2019. Disponível em: www.univali.br/direitoepolitica - ISSN 1980-7791

http://www.scielo.br/scielo.php?script=sci_arttext\&pid=S030376572012000200009. Acesso em: 02/02/2018.

STEARNS, Peter N. História das relações de gênero. São Paulo: Contexto, 2007. 250 p.

VAITSMAN, Jeni. Gênero, identidade, casamento e família na sociedade contemporânea. In: Mulher, gênero e sociedade. MURARO, Rose Marie (Org.). Relume Dumará. Rio de Janeiro. p. 13-20. 2001.

VALADÃO JÚNIOR, Valdir Machado. MENDONÇA, Juliana Moro Bueno. Assédio moral no trabalho: dilacerando oportunidades. Cad. EBAPE.BR, Rio de Janeiro: v. 13, n. 1, artigo 2, jan./mar. 2015. Disponível em: <http://www.scielo.br/pdf/cebape/v13n1/1679-3951-cebape-13-01-00019.pdf>. Acesso em: 15/07/2018.

RECEBIDO EM: 20/12/2018

APROVADO EM: 15/03/2019 